\title{
financeirização e novos espaços de acumulação: um estudo das transformações da hering após $1960^{\star}$ financialization and new spaces of accumulation: a study of the transformation of hering after 1960
}

\author{
Vanessa Follmann Jurgenfeld $\star \star$ \\ Faculdade de Ciências Sociais Aplicadas e Exatas, Universidade Federal dos Vales do Jequitinhonha \\ e Mucuri,Teófilo Ottoni, Minas Gerais, Brasil
}

Resumo

Este artigo discute as transformações do capital da empresa Hering após 1960, quando a crise no capitalismo mundial se inicia, embora suas repercussões no Brasil sejam sentidas mais tardiamente, nos anos 1980, com grande impacto negativo no setor têxtil nacional especialmente nos anos 1990 . É nesse período que há a abertura econômica, em meio a uma política neoliberal, com sobrevalorização da moeda, elevação dos juros e aumento da concorrência, por meio da entrada maciça de produtos têxteis importados. A partir de um estudo das transformações do capital da Hering após 1960, observa-se o avanço da financeirização, ao mesmo tempo que a empresa constrói novos espaços de acumulação.

Palavras-chave: Capital. Grande corporação. Hering.

\begin{abstract}
This article discusses the transformations of capital of the Hering company after 1960, when the crisis in world capitalism began, although its repercussions in Brazil were felt later in the 1980s, with great negative impact on the Brazilian textile sector especially in the 1990s. During this period, the economic opening takes place, amid a neoliberal policy, with overestimation of the currency and increased competition, through the massive entry of imported textile products. From a study of the transformations of the capital of Hering after 1960, the advance of the financialization is observed, at the same time that the company builds new spaces of accumulation.
\end{abstract}

Keywords: Capital. Great corporation. Hering.

* A autora agradece ao Conselho Nacional de Desenvolvimento Científico e Tecnológico $(\mathrm{CNPq})$ pelo financiamento da pesquisa.

Submetido: 3 de agosto de 2017; aceito: 1ํ de julho de 2018.

$\star \star$ Professora assistente da Faculdade de Ciências Sociais Aplicadas e Exatas da Universidade Federal dos Vales do Jequitinhonha e Mucuri. Doutoranda e mestra em Desenvolvimento Econômico pela Universidade Estadual de Campinas. E-mail: vfollmann@hotmail.com 


\section{Introdução}

Criada em 1880, a então chamada "Gebrüder Hering"" foi a primeira empresa têxtil de Blumenau (SC). Com ela se iniciou o processo industrial na região do Vale do Itajaí (SC) e, historicamente, a partir do capital dessa empresa alguns outros grupos têxteis surgiram no estado de Santa Catarina, no início do século XX, assim como empresas de energia, do setor financeiro e de alimentos.

Mais do que uma grande empresa, a Hering ${ }^{2}$ tornou-se um dos principais agentes do capitalismo nessa região. Historicamente, a família Hering teve papel relevante em instituições locais, com seus representantes assumindo cargos na direção de empresas de serviços essenciais, como energia, na fundação de hospitais e em órgãos de cultura, além de atuarem em cargos da administração municipal e como representantes de entidades de classe, como o sindicato das indústrias têxteis da região ${ }^{3}$. Essas funções mostravam o seu poder, além do fato de deter o capital de uma grande empresa local, influenciando a sua região de origem ao mesmo tempo que também recebera interferências desta no seu processo de desenvolvimento (Theis, 2000).

1 Gebrüder Hering (Irmãos Hering) foi o primeiro nome da Cia. Hering. Este foi também o nome que havia sido utilizado pela família Hering enquanto seus membros ainda moravam na Alemanha e detinham uma tecelagem e casa de atacado e varejo (Broos; Socorro, 1980). Ressalta-se ainda que Hermann Hering havia se formado mestre tecelão ainda na Alemanha, tendo experiência prévia nessa área (Hering, 1987).

2 Em 1915, após a morte de Hermann Hering, o nome da empresa passou a ser Hering \& Cia. e a direção da empresa foi para a segunda geração. Em 1929, ela se tornou uma sociedade por ações e a razão social mudou para Companhia Hering (Broos; Socorro, 1980).

3 São várias as atuações dos membros da família, como Max Hering, irmão do fundador, que foi administrador da Companhia Força e Luz de Santa Catharina, empresa de energia, além de ter participado da parte técnica da Companhia Telefônica da cidade de Blumenau, ter supervisionado a construção do Hospital Santa Catarina, um dos mais importantes hospitais da localidade. Outro irmão, Curt Hering, por sua vez, também participou da administração da Companhia Força e Luz de Santa Catharina, do Banco Agrícola de Blumenau, além de ter sido conselheiro municipal de Blumenau e então prefeito, um dos fundadores da Orquestra Sinfônica e presidente da Sociedade Dramático-Musical Carlos Gomes, nome do teatro da cidade de Blumenau. Outro irmão, Bruno Hering, foi um dos dirigentes da Associação Comercial de Blumenau (Broos; Socorro, 1980). 
A origem da Hering relaciona-se com a formação socioeconômica de Blumenau e de Santa Catarina ${ }^{4}$. Blumenau tornou-se a principal região de produção industrial de Santa Catarina no fim da década de 1950 e um dos maiores locais de produção têxtil do país (Mamigonian, 1965).

Uma análise que recaia sobre os movimentos históricos do capital de uma grande empresa, como é o caso da Hering, contribui para o debate das mudanças do sistema capitalista sob o foco da grande corporação, uma vez que esta se tornou o mais importante agente do capitalismo moderno, sendo ator fundamental, principalmente, no que diz respeito à financeirização e à reorganização espacial capitalista a partir de meados dos anos $1960^{5}$ (Braga, 1997; Corrêa, 2010).

Este artigo tem como foco apreender as principais transformações do capital que compõe a grande empresa Hering e que determina a sua estratégia. São discutidas as mudanças desse capital, especialmente, a partir da crise capitalista mundial que se inicia nos anos 1960, com desregulamentação e liberalização dos mercados financeiros mundiais, contribuindo para, nos anos 1970, haver o rompimento dos acordos de Bretton Woods, que resultaram em modificações profundas no sistema capitalista, com o fim do padrão de acumulação dado pelo dólar-ouro e ampliação das inovações financeiras.

A pergunta que guia este artigo é: Quais foram as transformações no capital da Hering diante das mudanças do capitalismo mundial, sobretudo a partir dos anos 1960? Como isso influenciou a sua estratégia e alterou a organização espacial das suas atividades?

Os momentos de crise sistêmica são representativos de fases de queima e destruição desorganizada de riqueza não socialmente sancionada pelos mercados. Esses períodos revelam a lógica maior que preside a dinâmica do sistema capitalista. São, portanto, momentos importantes

4 Embora não seja objeto deste artigo entender a formação socioeconômica de Blumenau, cumpre ressaltar, porém, o trabalho pioneiro sobre a dinâmica econômica do setor têxtil da região feito por Mamigonian (1965). Entre outros estudos mais recentes em relação à importância industrial do setor têxtil para o Vale do Itajaí e para Santa Catarina, sugere-se: Lins (2000) e Jurgenfeld (2009). Sobre a formação econômica de Santa Catarina, recomenda-se Goularti Filho (2007). Sobre a formação de Blumenau, ver Theis (2000).

5 O espaço que aqui se faz referência é o espaço social. Santos (1996) o define como uma configuração territorial determinada por relações de produção, que, por fim, são relações sociais. 
para se analisar os movimentos do capital, sobretudo do capital dinheiro D-D' (Brandão, 2010).

Em linhas gerais, os anos 1960 e 1970 caracterizam-se pela busca de novos espaços de acumulação pelo capital mundial e de novas formas de valorização por meio da financeirização ${ }^{6}$. Entende-se que, em meio a esse processo mais geral de ampliação da financeirização e de alterações nas estratégias concorrenciais entre as empresas dominantes ${ }^{7}$, a Hering também se transformou. A entrada do capital financeiro ocorreu com a abertura de seu capital em bolsa de valores na década de 1960, e, posteriormente, ganhou proporções maiores quando, entre os anos 1990 e 2000 , houve um ingresso expressivo de acionistas do mercado, como os fundos de investimentos, como sócios do negócio, cujas participações em conjunto superariam as dos representantes da família fundadora.

$\mathrm{Na}$ economia mundial, os anos 1990 constituíram-se, de fato, como um período de aprofundamento da financeirização, com maior atuação de bancos, fundos de pensão e de investimentos no quadro societário de grandes empresas. Desde então, eles passaram a deter um duplo poder: o de sócios das operações e o de credores. De acordo com Sauviat (2005), independentemente da forma aparente, sempre se comportarão, contudo, como traders, preocupados com o lucro a curto prazo. Assim, não hesitarão em se retirar rapidamente de uma empresa, mesmo ela sendo "sadia" do ponto de vista das suas informações financeiras, se não houver perspectivas de um bom lucro a curto prazo. Para esses sócios, não importará também se os novos investimentos da empresa serão em elevação da capacidade produtiva ou se em meros investimentos especulativos no mercado financeiro, desde que ocorra uma adequada rentabilidade por meio de dividendos em um curto espaço de tempo.

Nas palavras de Chesnais, a partir dos anos 1990, a economia mundial carregaria, de forma efetiva, a marca de um capitalismo predominante-

6 Sobre esse período de transformações do capitalismo, há várias referências importantes. Entre elas sugere-se Block (1980), Chesnais (1995, 1996), Hobsbawm (2016) e Wachtel (1988).

7 Conforme Belluzzo (2005), a grande empresa direcionou-se para uma internacionalização do tipo multimercados e multimoedas, de modo que, com o avanço do capital financeiro, também ocorreram processos de relocalização espacial. Tais mudanças terão reflexos específicos em economias periféricas pelo alargamento do espaço do centro e pelas inserções distintas da periferia nessa dinâmica. 
mente rentista e parasitário, cujo funcionamento pareceria “estar subordinado, de modo crescente, às necessidades próprias das novas formas de centralização do capital-dinheiro, em particular os fundos mútuos de investimento (mutual investment funds) e os fundos de pensão" (Chesnais, 1995, p. 2).

A política de abertura econômica no Brasil nesse período deu margem à chegada de fundos internacionais não só pela desregulamentação e liberalização de mercados, mas também pela elevação das taxas de juros e pela sobrevalorização da moeda no Plano Real, implantado em 1994, que aumentavam as oportunidades de ganhos rentistas por esses agentes.

O avanço desses novos sócios, no entanto, não deve ser entendido como se as grandes empresas industriais fossem "vítimas" desse capital entrante, mas partícipes do processo de alteração do seu capital e de ampliação da financeirização mundial ${ }^{8}$ (Braga, 2000).

Analisa-se neste artigo o capital que compõe a Hering nas suas mais variadas apresentações (comercial, industrial, financeiro) ${ }^{9}$, com o objetivo de entender o controle que orienta a sua estratégia, ao longo de uma periodização do movimento histórico de sua acumulação:
1) de 1880 até a Segunda Guerra Mundial;
2) do pós-guerra até 1980 ;
3) entre 1990 e a década de 2000.

Ao mesmo tempo que serão discutidas as transformações do capital da Hering, sobretudo nessa etapa mais avançada do capitalismo, busca-se

8 As grandes empresas não só abriram a possibilidade de ingresso de novos sócios do mercado financeiro no seu capital social como elas mesmas passaram a operar no mercado financeiro, em aplicações rentistas, por meio de tesourarias próprias ou por meio de contratação de uma instituição para intermediação financeira, dando sustentação à financeirização da qual, portanto, também seriam agentes.

9 Não se pretende fazer um debate sobre as formas particulares do capital, que, dada a complexidade, excederia os limites deste artigo. Trata-se aqui da sua forma aparente. No entanto, para uma discussão mais profunda no Brasil sobre o papel do capital mercantil, que se divide em comercial e usurário, recomenda-se Cano (2010). Sobre o debate do capital financeiro na transição do século XIX para o XX, são sugeridas as obras de Hilferding (1985) e Hobson (1993). Para uma discussão mais recente sobre capital financeiro, recomenda-se Chesnais (1996). 
entender como esse movimento também levou a alterações na sua estratégia e na configuração espacial das suas atividades, porque as relações de produção são simultaneamente sociais e espaciais. Há como parâmetro a interpretação de que a expansão espacial é produto necessário para o processo de acumulação, uma vez que os novos espaços são criados porque a acumulação de capital se destina a ser geograficamente expansível e faz isso pela progressiva redução do custo de comunicação e transporte $^{10}$ (Harvey, 2005).

Para a discussão da Hering pós-1960, necessário se faz retomar alguns aspectos da sua origem, até para que seja, de fato, possível caracterizar aquilo que se entende como transformação. A primeira parte deste artigo, portanto, analisa o capital na origem do grupo Hering, em 1880, até a Segunda Guerra Mundial. Na segunda parte, serão debatidas as principais mudanças no seu capital entre os anos 1960 e 1980, quando há abertura de capital em bolsa de valores e novos espaços são construídos para a sua acumulação. Por fim, o artigo tratará das modificações do capital ocorridas entre os anos 1990 e os 2000, período que compreende uma crise têxtil no país, a exacerbação da financeirização, a criação de novos espaços de acumulação mais distantes da sua região de origem e uma estratégia também mais relacionada a sua atuação comercial, tanto pela ampliação da rede de lojas como pela compra de produtos prontos fabricados por terceiros para revenda.

\section{De 1880 até a Segunda Guerra Mundial: os anos iniciais da empresa}

A Gebrüder Hering foi a primeira empresa industrial de Blumenau, uma iniciativa do alemão Hermann Hering, imigrante de Hartha, na Saxônia, que chegara ao local no fim da década de 1870, com algumas

10 Harvey, reproduzindo Marx, entende que "o aumento da 'velocidade de circulação do capital' contribui para o processo de acumulação. Nessas condições, até a distância espacial se contrai em relação ao tempo: o importante não é a distância do mercado no espaço, mas a velocidade [...] pela qual o mesmo pode ser alcançado. Assim, há um grande estímulo para a redução do tempo de circulação a um mínimo, pois isso minimiza 'o período de perambulação' das mercadorias. Desse modo, uma necessidade dual, tanto para reduzir o custo quanto o tempo envolvidos no movimento, origina-se do imperativo da acumulação" (Harvey, 2005, p. 50-51). 
economias da Alemanha. Nos seus primeiros anos em Blumenau, trabalhou em algumas atividades e chegou a abrir uma venda ${ }^{11}$.

A empresa têxtil propriamente seria criada em 1880, quando, além de recursos próprios, Hermann Hering utilizou economias de colonos mais prósperos do Vale do Itajaí (SC), que colocavam seus recursos na formação de empresas. A falta de bancos ${ }^{12}$ fazia com que colonos oferecessem capital proveniente do excedente da sua lavoura aos novos negócios pela confiança que neles depositavam. Havia o empréstimo direto às empresas e também aos colonos que depositavam os recursos em casas comerciais ${ }^{13}$ e estas repassavam o dinheiro para a empresa industrial, fazendo as vezes de intermediárias financeiras. Como a quantia acumulada por colono não era alta, geralmente, quando os empresários utilizavam tais recursos, recorriam a um grupo de colonos para ter um capital suficiente.

11 De acordo com Hering (1987), a venda ou pequena casa comercial também era sinônimo de botequim, segundo os registros daquela época.

12 Somente em 1907 foi criada a primeira instituição de crédito na região por iniciativa de colonos e comerciantes. Ela era uma caixa econômica e de empréstimos, anexa ao sindicato agrícola blumenauense. Em 1936, pela reforma do estatuto desse sindicato, foi criado o primeiro banco: Banco Agrícola e Comercial de Blumenau (Hering, 1987).

13 É importante ressaltar que as casas comerciais eram as famosas casas de importação e exportação. E, assim como é registrado em boa parte do Brasil, eram comércios dominados por imigrantes que, graças às suas origens sociais, encontram lugar nessa atividade controlada em parte por empresas estrangeiras. Dean (1971) trabalhou a relação entre os importadores e o setor industrial, mostrando a posição estratégica do importador no início da constituição das indústrias no país, pelo seu acesso ao crédito, conhecimento de mercado e por serem canais de distribuição de produtos finais. Alguns possuíam participação em manufaturas que lhe asseguravam a distribuição exclusiva de seus produtos. Além disso, Dean (1971) ressaltou que posteriormente os importadores converteram suas vendas em fábricas autorizadas. E outros se tornaram o próprio empresário industrial. Conforme Silva (1986), o comércio se constituiu como uma importante base de apoio para o início da acumulação. E, em razão do controle do capital comercial, muitas vezes o importador está na origem das empresas industriais que se constituem no país como um todo após 1880 . 
Além disso, a Hering contou com recursos do próprio colonizador Dr. Blumenau ${ }^{14}$, que lhe emprestou dinheiro após a empresa ser destruída por uma enchente em $1880^{15}$ (Hering, 1987).

A empresa têxtil iniciou-se a partir da instalação de um primeiro tear circular, adquirido juntamente com um caixote de linhas, em 1879, na cidade vizinha de Joinville. A intenção de Hermann Hering era atender inicialmente as necessidades regionais de meias, até porque não havia muita facilidade de acesso a outras áreas do país, que contava com poucas estradas. Além de Hermann Hering, trabalharam na formação da empresa sua esposa, seus filhos e seu irmão (Hering, 1987).

Em pouco tempo, a empresa mudou-se do centro de Blumenau para uma área própria, na zona rural, próxima à queda d'água do ribeirão Bom Retiro, a 3 quilômetros do centro. A transferência permitia o uso da água no processo produtivo, a produção de energia a partir da queda d'água, além de uma aproximação aos trabalhadores rurais, que viriam a ser os seus colonos-operários ${ }^{16}$.

Em 1893, a Gebrüder Hering tinha 15 empregados, em 1900 chegava a 30 e passava a 300 empregados em 1914 (Hering, 1987). Em 1915, a empresa diminuía a sua dependência de importação de fios, tendo criado uma fiação para sua própria fabricação, com o uso do algodã ${ }^{17}$ do Nordeste, o que lhe deu grande impulso diante da Primeira

14 Dr. Blumenau foi o colonizador do local. Seu nome era Hermann Bruno Otto Blumenau. Ele era da Alemanha e se instalou no país para formar a colônia Blumenau. Chamavam-no de Dr. Blumenau por ser formado em química e filosofia. Aos 31 anos, ele soube do projeto de colonização de terras devolutas pelo governo imperial brasileiro e lhe fez uma proposta. Ao conseguir terras - uma parte doada pelo governo e outra parte comprada por ele -, decidiu iniciar em 1850 um núcleo colonial privado (Deeke, 1995).Após alguns anos, envolto em dívidas com o governo, a colônia de Blumenau se tornaria pública. Foi criado o município de Blumenau em 1880.

15 A bacia do rio Itajaí-Açu é a maior de Santa Catarina e localiza-se em uma área de grande precipitação, havendo enchentes periódicas.

16 O "colono-operário" geralmente trabalha parte do tempo na empresa e parte na sua lavoura própria. Conforme Hering (1987), essa condição lhe conduzia a uma vida modesta porque tinha escolaridade, em geral, de apenas três anos e porque havia, afinal, duas atividades às quais deveria se dedicar.As possibilidades de aperfeiçoamento e mobilidade social eram poucas em uma terra com lavoura estagnada e indústria nascente.

17 A Hering chegou, juntamente com a empresa Renaux, a tentar a produção de algodão em Santa Catarina, mas essa experiência não deu certo (Hering, 1987). 
Guerra Mundial, quando houve rompimento das importações devido ao próprio conflito (Broos; Socorro, 1980).

Davam impulso à expansão da empresa a energia mais barata com a inauguração da Usina Salto em 1915, da então Companhia Força e Luz de Santa Catharina ${ }^{18}$, e as linhas telefônicas recém-instaladas.

A partir do fim da Primeira Guerra Mundial e durante a década de 1920, a indústria têxtil assumiria um papel mais significativo no interior da economia catarinense ${ }^{19}$ e, com ela, a Hering. Esta passaria a realizar investimentos em novos negócios industriais têxteis, além de adentrar em novos setores.

Pelo menos até 1929, momento da Crise de 1929, houve um grande ciclo de investimentos industriais no Vale do Itajaí (SC), região que compreende Blumenau. Foram criadas as seguintes empresas têxteis: Altenburg, Haco, Fábrica de Chapéus Clesen \& Weege, Malhas Thiemann, Indústrias Renaux, Mafisa e Teka. Após a Crise de 1929, entre a segunda metade da década de 1930 até a Segunda Guerra Mundial, houve ainda criação da Cremer, da Artex e da Indústria de Linhas Leopoldo Schmalz (Jurgenfeld, 2012).

Interessa para este artigo principalmente a iniciativa naquele período da criação da Malharia de Artefatos Finos S/A, que anos depois se chamaria Malharia Blumenau (Mafisa). Essa empresa, nascida com sete operários e apenas dois teares, contou com recursos da Hering. Dentre os sócios havia netos de Hermann Hering, que realizaram estudos na área têxtil na Saxônia, e a própria Hering, que foi uma das sócias do novo negócio, com uma participação de $25 \%$. A linha de produtos inicial constituiu-se de artigos de lingerie com a malha charmeuse. Depois,

18 Antes de 1955, quando da criação das Centrais Elétricas S/A (Celesc) pelo estado, a energia em Santa Catarina era provida por várias pequenas empresas privadas. Entre elas havia a Companhia Força e Luz de Santa Catharina, responsável pela Usina do Salto (Livro de ouro comemorativo do Centenário da Independência do Brasil e da exposição internacional do Rio de Janeiro, 7 de setembro de 1922 a 7 de setembro de 1923, 1922, p. 113). Essa empresa surgiu tendo como sócios empresários de Blumenau e de São Paulo, sendo sua sede inicialmente em São Paulo e, posteriormente, foi transferida para Blumenau (Broos; Socorro, 1980).

19 Esta foi uma etapa de substituição de importações porque havia uma demanda interna não atendida em função do colapso do comércio internacional, entre outros efeitos negativos, da Primeira Guerra Mundial. 
passou a camisolas, camisas, calças, pijamas etc. (Folheto Institucional da Empresa Mafisa, s.d.)

Além da Mafisa, observa-se que em 1918 a Hering também teria se tornado sócia majoritária da Empresa Industrial Garcia, tecelagem de algodão localizada em Blumenau, fundada em 1885, com compra de participação. E em 1935 a Hering participara da criação da Cremer, voltada para produção de artigos têxteis para uso cirúrgico e hospitalar, tornando-se um representante da família,Victor Hering, sócio do então comerciante Alwin Schrader e do imigrante alemão Werner Cremer.

Apesar de 1929-1930 representar no Brasil uma crise do café e não da indústria, ambos os setores estavam inter-relacionados porque "as cotações [internacionais] dos produtos de exportação regulavam o poder aquisitivo dos trabalhadores rurais e suas famílias que, por sua vez, eram os consumidores dos tecidos grossos produzidos pela maioria das fábricas brasileiras" (Stein, 1979, p. 124).

A crise da cafeicultura levou à falência algumas têxteis do Sudeste, mais sujeitas diretamente aos efeitos sobre a demanda de seus produtos, pela dependência que tinham da dinâmica econômica dada pelo café. Alguns dos concorrentes dessas empresas - diante das restrições para importar - acabaram comprando os equipamentos dessas organizações falidas, portanto, equipamentos de segunda mão, conseguidos dentro do próprio país. A Hering será uma das compradoras e reativará uma dessas empresas de São Paulo em 1943, que ganhará a denominação “Meias Hering".

O crescimento da Hering entre os anos 1920 e 1940 pode ser representado pelo seu número de funcionários, que passaria de 500, em 1929, para 771 , em 1940, e para 878 , em 1945. Sua produção passaria de 76 mil dúzias de camisetas, em 1929, a 144 mil, em 1936, e a 183 mil, em 1943 (Hering, 1987).

Também será entre as décadas de 1920 e de 1940 que, além de começar uma movimentação no sentido do Sudeste, a Hering investirá seus lucros acumulados em outros setores no Vale do Itajaí (SC).

A fim de mostrar a importância que adquiriria a empresa a partir desse período, o Quadro 1 resume os principais investimentos da Hering entre 1920 e 1940 em aço, papel e energia, além dos recursos destinados a participações em outras empresas do próprio setor têxtil, anteriormente citadas. 
Quadro 1 - Derivações do capital da Hering (1920-1940)

\begin{tabular}{|l|}
\hline $\begin{array}{l}\text { A Hering adquiriu as ações da Companhia Força e Luz de Santa Catharina, criada em } 1915 \\
\text { e proprietária da usina do Salto. A Hering se tornou sócia da empresa na década de } 1920 .\end{array}$ \\
\hline $\begin{array}{l}\text { Do capital da Hering, também saiu parte da compra da Empresa Industrial Garcia. A Hering } \\
\text { se tornou acionista majoritária dessa empresa a partir de } 1918 .\end{array}$ \\
\hline $\begin{array}{l}\text { Do capital da Hering, em parte saíram recursos para a constituição da Cremer em 1935, } \\
\text { uma vez queVictor Hering foi um dos sócios na sua formação. }\end{array}$ \\
\hline $\begin{array}{l}\text { Do capital da Hering, entre } 1930 \text { e 1940, saiu também investimento para criação de empresa } \\
\text { de beneficiamento de madeira e papel, a Companhia Fábrica de Papel Itajá. }\end{array}$ \\
\hline Da Hering saiu parte do capital para constituição da Malharia Blumenau (Mafisa) em 1929. \\
\hline $\begin{array}{l}\text { Do capital da Hering, nasceu, em parte, a Electro Aço Altona em 1933. O fundador Paul } \\
\text { Werner havia sido contratado por Curt Hering, que fora prefeito do município, para instalar } \\
\text { rede telefônica em Blumenau, e teve apoio financeiro de Curt Hering, segunda geração da } \\
\text { família Hering, para começar a empresa do ramo de aço. }\end{array}$ \\
\hline A Hering participou da criação do Banco Agrícola e Comercial de Blumenau em 1936.
\end{tabular}

Fonte: elaboração própria a partir de Bossle (1988), Broos; Socorro (1980), Hering (1950), Hering (1987), Mamigonian (1965), Seyferth (1974), Vidor (1995).

Em relação ao madeireiro são importantes algumas considerações sobre a sua história ainda no século XIX, antes de se tratar das modificações nos anos 1940, pois dele observa-se uma relação da Hering com a produção de papel e o setor bancário.

A exploração da madeira historicamente existiu desde o início da colonização doVale do Itajaí, iniciada em 1850, e guardava relação direta com a família Odebrecht, a partir de Emílio Odebrecht, engenheiro alemão contratado por Dr. Blumenau para medição de terras para divisão de lotes na região. Mas foi seu filho, Rodolpho Odebrecht, quem de fato iniciou os negócios no ramo da madeira, quando criou uma fábrica de esquadrias para exportação em Rio do Sul, cidade no Alto Vale do Itajaí, nos anos 1930.A Rodolpho Odebrecht logo se associaram empresários do setor têxtil, como Max e Curt Hering. Poucos anos depois, houve a entrada de Otto Renaux, da Fábrica Têxtil Renaux, nos negócios.

Durante a Segunda Guerra Mundial, contudo, as reservas de madeira começaram a se esgotar no Vale do Itajaí, assim como o fornecimento de máquinas para essa atividade, que também eram importadas e sofriam, como o maquinário têxtil, restrições por conta da paralisação do comércio mundial em razão do conflito. Com o fim das reservas, a atividade madeireira transferiu-se do Vale do Itajaí para Lages (SC). Essa área, 
conhecida por sua reserva de araucárias, passou a ser explorada por um cultivo comercial dado pela espécie pinus elliotti e pinus taeda, de alta produtividade. Nessa época, houve investimentos da Hering novamente no ramo, a fim de explorar a produção de papel por meio da Companhia Fábrica de Papel de Itajaí (Hering, 1950).

O ramo da madeira também acabou atraindo Irineu Bornhausen, que futuramente se tornaria governador de Santa Catarina. Ele se tornou sócio da empresa Gropp S/A, fundada em Rio do Sul. Bornhausen associou-se a Otto Renaux por meio das atividades da madeira, e nessa união houve a ideia de criação de um banco catarinense, o Banco INCO (Banco Indústria e Comércio de Santa Catarina).

$\mathrm{O}$ Banco INCO, contudo, não foi o primeiro banco da região. $\mathrm{O}$ primeiro foi o Banco Nacional do Comércio de Porto Alegre. O Banco do Brasil só surge na região como emprestador de recursos após a Segunda Guerra Mundial. O INCO tinha sede em Itajaí, local pelo qual era escoada historicamente a produção da região.Várias pessoas da área de comércio e transporte do Vale do Itajaí entraram no negócio bancário criado por Renaux e Bornhausen como sócios: Bonifácio Schmidt, Victor Konder, Rodolfo Renaux Bauer, Fritz Schneider, Nestor Schieffler, Arno Bauer, Augusto Voigt, Antonio Ramos, Francisco Almeida e José Menescau do Monte (Hering, 1987).

Para entender a relação da Hering com esse setor bancário, destaca-se que do capital da Hering havia derivado parte do dinheiro para a criação do Banco Agrícola e Comercial de Blumenau, fundado em 1936, que então foi incorporado pelo INCO em $1942^{20}$.

20 O Banco INCO tornou-se, assim, a principal instituição de crédito em Santa Catarina. Ele atuou inclusive no financiamento de obras públicas em municípios. $\mathrm{O}$ Banco INCO acabou incorporado em 1968 pelo Bradesco. Ou seja, apesar de sua centralização no estado de Santa Catarina, com diversas incorporações, o INCO também fazia parte, obviamente, de um sistema maior, o sistema bancário nacional, no qual outros concorrentes tinham mais poder de fogo e, em meio também a um movimento de centralização, adquiriram o Banco INCO, dentre outros bancos regionais. 


\section{Do pós-guerra aos anos 1980: a abertura de capital em bolsa e as novas espacialidades}

Após o conflito bélico, a Hering incrementou a exportação de seus produtos têxteis ${ }^{21}$, abriu seu capital, entrou no setor de alimentos e assumiu uma posição importante na área têxtil do país. As décadas de 1960 e 1970 representariam um período de concentração e centralização do capital da Hering e de inserção de novas áreas geográficas de produção industrial têxtil nos seus negócios. Isso envolvia a instalação de fábricas em municípios próximos a Blumenau e uma primeira ida ao Nordeste.

Os novos espaços serão inseridos na dinâmica capitalista de maneira diferenciada, reproduzindo a própria forma de crescimento do capitalismo, por meio de um desenvolvimento geograficamente desigual e combinado $^{22}$. Assim, as novas áreas geográficas farão parte de uma espacialização complexa e distintiva. Haverá, portanto, uma uniformidade dos espaços no sentido de que se integrarão a um mesmo processo de acumulação do capital (dado pela própria empresa), mas será justamente essa uniformidade sob a lógica do capital que levará à diferenciação desses mesmos espaços ${ }^{23}$ (Brandão, 2007; Soja, 1993).

A procura desse capital não se restringirá a novos espaços físicos de produção. Buscará novos locais de comercialização e consumo, além de ampliar a financeirização. Há, a partir de então, um capital financeiro em ascensão na estrutura de capital, que poderá inicialmente ser observado pela abertura de capital em bolsa de valores.

Com essas transformações, a Hering se conformará como um grande grupo nos anos 1980, com atuação em diferentes setores e regiões do país.

21 Houve uma política de incentivos às exportações pelo governo federal, inaugurada em 1972 sob denominação "Benefícios Fiscais à Exportação" (BEFIEX). De acordo com Siebert (2006), ela concedia reduções de Imposto de Renda, isenções de Imposto sobre Produtos Industrializados (IPI) e do Imposto sobre Circulação de Mercadorias (ICM), crédito-prêmio, entre outros incentivos.

22 Essa expressão é originária de Trotsky (1978). Como bem observa Theis e Butzke (2012), é importante reter que a existência simultânea e dinâmica de espaços economicamente mais e menos pujantes é resultado do desenvolvimento geograficamente desigual. E, ao mesmo tempo, é condição para o processo de continuada valorização de capital.

23 Em termos concretos, haverá locais que serão inseridos no processo de acumulação da empresa enquanto área produtora de matérias-primas, outros enquanto provedores de mão de obra barata e outros por custos de impostos menores etc. 


\subsection{Abertura do capital}

A Hering abriu o seu capital em bolsa de valores em $1966^{24}$. A bolsa de valores e os novos sócios "investidores" representaram uma nova forma de obtenção de recursos para investimentos e financiamento das próprias expansões fisicas da empresa.

Stein (1979) melhor explica esse movimento, que se dava entre várias empresas do setor, dizendo que, perto do fim da Segunda Guerra Mundial, os fabricantes tradicionais têxteis, que abasteciam os mercados externos nos quais o Brasil agora entrara, estavam preparados a retomar tais mercados, com preços mais baixos do que os praticados pelas empresas têxteis brasileiras. Nesse momento, as empresas brasileiras apelaram à ajuda do governo, como era costumeiro, para modernização de suas fábricas porque os preços das novas máquinas, necessárias para fazer frente a um novo período de forte concorrência no pós-guerra, dispararam. O governo não acenou com grandes possibilidades de ajuda e, como alternativa para levantar recursos de forma mais rápida, buscaram a emissão de ações em bolsas de valores.

A abertura fornecia uma captação de recursos mais barata do que o crédito bancário. Como lembra Tavares (1975), contudo, essa abertura do capital ocorria no Brasil, justamente, em um período de aumento da concentração bancária no país, que tinha como efeito colateral para as empresas em geral a restrição do crédito, ampliando a sua dependência de um número cada vez mais reduzido de grupos bancários. A contrapartida era que as empresas aumentavam seus riscos, pois possuíam a partir de então o compromisso de pagamento de dividendos aos seus novos acionistas.

\subsection{A criação da Ceval}

Como parte da ampliação da sua diversificação em meio ao processo de financeirização em curso, em 1972 a Hering entrou no setor agrícola, iniciando operações no complexo da soja, a commodity pela qual o país passaria a ser reconhecido internacionalmente anos depois. Da soja,

24 Informação do histórico da empresa. Disponível em <http://hering.riweb.com.br/ show.aspx?idCanal=EORk2uij8WX1wYdhlRD0Lg==>, acesso em 20 de julho de 2018. 
partiu para produção de frangos e suínos. Ela criou a Cereais doVale do rio Itajaí-Açu (Ceval).

A Ceval, com sede na cidade de Gaspar (SC), de acordo com relato da própria empresa, nascia "da necessidade de diversificação produtiva e de negócios da centenária Hering" (Folheto Institucional da Empresa Ceval, 1992, p. 4).

A Ceval representava o beneficiamento de soja dos três estados do Sul. Com ela, também houve investimentos em infraestrutura de escoamento da produção via porto de São Francisco do Sul (SC), criação de uma trading no exterior para comércio e meios de transporte próprios. Por meio da Seara Industrial S/A, a Hering passou à produção, ao abate e à comercialização de suínos e aves (Vieira Filho, 1986).

A Ceval chegou a ter no início dos anos 1990 unidades instaladas em 14 estados brasileiros e em 4 províncias argentinas, com cerca de 15 mil empregados, tendo "relacionamento" com 40 mil produtores rurais brasileiros, argentinos, paraguaios e bolivianos, que lhe forneciam milho, soja, frangos e suínos pelo sistema de integração ${ }^{25}$, principalmente. Dentre as marcas que ela comercializava, estavam Soya,Ville, Mileto, Bonna, All Day, Seara, entre outras.

Dos ramos de atuação da Ceval, o negócio da soja, contudo, era o mais relevante, segundo a própria empresa:

Com a soja, a Ceval saiu de Gaspar (SC) e expandiu-se para o oeste de Santa Catarina, Rio Grande do Sul, Paraná, Centro-Oeste, aos cerrados do Nordeste e, recentemente, à Argentina. Foi também em consequência da soja que a Ceval iniciou a sua participação no negócio da industrialização das carnes de aves e suínos, em 1980, e nos produtos à base de milho, em 1988. (Folheto Institucional da Empresa Ceval, 1992, p. 8)

O negócio de carne surgia justamente porque a empresa nos anos 1980 produzia farelo de soja para rações animais e via possibilidade de transformar a proteína vegetal em proteína animal. Bastava para isso "dar uma forma de consumo a uma commodity para que se tornasse um pro-

25 Pelo sistema de integração, os produtores são como terceirizados da empresa. Produzem conforme as especificidades dadas pela empresa, mas em sua própria propriedade. Há uma série de regras e investimentos que devem ser cumpridos pelo produtor e, geralmente, há contrato de exclusividade no fornecimento. 
duto para o consumidor final" (Folheto Institucional da Empresa Ceval, 1992, p. 32). Assim, começou a comprar frigoríficos na área de frangos e suínos em Santa Catarina.

A Ceval era uma das líderes no movimento de concentração de capital do setor agropecuário nacional. Em 1995, adquiriu a empresa Guipeba, uma das maiores processadoras de soja da Argentina, que detinha, além de fábricas para processamento de grãos, terminais portuários e silos de armazenagem. No segmento de carnes, também buscou a concentração ao adquirir nos anos 1990 a Agroeliane ${ }^{26}$, indústria de alimentos que tinha unidades em Forquilhinha (SC) e Sidrolândia (MS).

A dimensão da Ceval pode ser observada a partir da produção de aves e suínos. Em 1994, ela era a terceira maior empresa de aves do Brasil, ficando atrás somente da Sadia e da Perdigão no volume de aves abatidas por ano, bem como na sua capacidade anual de abates de suínos. Assim como Sadia e Perdigão, a Ceval organizava todo o sistema de criação, abate e distribuição de forma integrada, obtendo o controle da cadeia produtiva (Campos, 2001).

A Ceval, portanto, representava um negócio importante da Hering e uma de suas principais frentes de expansão, sendo algumas vezes maiores do que a Hering em faturamento (Jurgenfeld, 2012) ${ }^{27}$.

\subsection{Novos espaços na região do Vale do Itajaí}

Ao mesmo tempo que aumentava a financeirização e realizava a diversificação para novos setores, a Hering "reorganizava" a sua produção têxtil com desintegração produtiva. Em termos socioespaciais, durante a década de 1970, ganharam importância as cidades do entorno de Blumenau.

A expansão da atividade têxtil da Hering para fora de Blumenau era acompanhada por alterações nas formas organizacionais do trabalho industrial no capitalismo, que permitiu a dispersão espacial e a intensificação dos fluxos entre as etapas produtivas. Isso seguia uma tendência

\footnotetext{
26 A Agroeliane pertencia à empresa Eliane, hoje conhecida mais pela produção de pisos e revestimentos cerâmicos, localizada em Cocal do Sul (SC).

27 A Hering, contudo, decidiu sair do setor de alimentos e grãos, no fim dos anos 1990, em meio à crise têxtil. As mudanças dos anos 1990 e 2000 serão abordadas mais adiante.
} 
no setor têxtil mundial, que passava a se organizar dessa forma, possibilitado pela microeletrônica, que permitia que os processos fossem separados (desverticalizados) sob comando à distância da matriz.

Os municípios vizinhos a Blumenau receberam nesse período etapas da produção muito relacionadas à necessidade de uso intensivo de mão de obra, como corte e costura. A Hering criaria filiais nos municípios de Indaial (antigo Encano), Ibirama e Rodeio, e na própria cidade de Blumenau, com confecções instaladas nos bairros de Água Verde e de Itororó, mais distantes do centro da cidade (Siebert, 2006).

O Quadro 2 dá uma ideia de como ficou organizada a produção da Cia. Hering em Santa Catarina na década de 1980, somando as instalações mais antigas com as recém-criadas.

Quadro 2 - Unidades produtivas da Cia. Hering em Santa Catarina, na década de 1980

\begin{tabular}{|l|l|}
\hline \multicolumn{1}{|c|}{ LOCALIZAÇ̃̃o } & \multicolumn{1}{c|}{ FUNÇÃo } \\
\hline Blumenau - Bairro Bom Retiro & Matriz \\
\hline Blumenau - Bairro Bom Retiro & Fiação \\
\hline Blumenau - Bairro Bom Retiro & Malharia \\
\hline Blumenau - Bairro Itororó & Corte, estampa, bordado, embalagem, beneficiamento \\
\hline Blumenau - Bairro Itoupava & Lavanderia, acabamento \\
\hline Blumenau - Bairro Água Verde & Confecção \\
\hline Indaial - Bairro Encano & Confecção \\
\hline Rodeio - Bairro Gávea & Confecção \\
\hline Ibirama - Bairro Ponto Chic & Confecção \\
\hline
\end{tabular}

Fonte: Luclktenberg (2004).

De acordo com o Quadro 2, Indaial, Rodeio e Ibirama, além da unidade no Bairro Água Verde, em Blumenau, se integrarão à cadeia produtiva da empresa por meio da etapa da confecção - aquela em que a tecnologia ainda seria apenas da máquina de costura, cuja automação não evoluiu a ponto de dispensar a costureira. A matriz continuará concentrada em Blumenau, com o apoio de etapas mais complexas de produção feitas em outras unidades na própria cidade de Blumenau. Apoiando-se em Soja (1993) e em Brandão (2007), pode-se dizer que o movimento deixa nítido que existia uma polarização e uma hierarquia dos espaços de produção na realocação produtiva da Hering. 


\subsection{A primeira produção industrial no Nordeste}

Entre meados dos anos 1960 e durante os anos 1970, o Nordeste também apareceria como uma das opções de expansão da produção têxtil da Hering. O governo federal promovia esse direcionamento, uma vez que acenava com uma política de descentralização industrial, com promoção de incentivos fiscais por meio, principalmente, da Superintendência do Desenvolvimento do Nordeste (SUDENE), criada em 1959.

O deslocamento do capital do setor têxtil catarinense rumo ao Nordeste resultou na criação da Têxtil Catarinense do Nordeste (Tecanor), uma união de Artex, Teka e Hering, que instalou uma fábrica têxtil em Paulista (PE), ainda em 1966. Mas diversos sócios se retiraram do negócio anos depois. A Hering adquiriu as fatias dos sócios retirantes.

Em 1976, a SUDENE aprovou projeto de implantação em Paulista, no estado de Pernambuco, transformando a Tecanor em uma unidade Hering, que a partir de então criaria a Hering Nordeste.

O avanço para o Nordeste não representou deslocamento do centro de comando da empresa, que permaneceu em Blumenau. Assim como ocorreu nos municípios vizinhos a Blumenau, as regiões do Nordeste receberam, principalmente, as etapas de produção que mais precisavam de mão de obra, como a costura. Isso novamente guardava relação com a polarização e hierarquia dos espaços de produção sob a lógica de acumulação da empresa.

\subsection{0 grande grupo dos anos 1980}

A maior escala dada pela concentração e centralização do capital da Hering durante a década de 1970 exigirá a formação de uma nova estrutura organizacional, dada pela criação de uma holding e de suas subsidiárias, responsáveis pelas mais diversas divisões, tanto regionais quanto setoriais. Para se ter uma ideia do gigantismo da Hering, ela aparecerá na década de 1980 dentre os maiores grupos privados nacionais ${ }^{28}$ (Tabela 1).

28 São diversos os critérios usados pela publicação para classificação dos maiores grupos privados nacionais, havendo diferentes cruzamentos de dados. Ver Balanço Anual da Gazeta Mercantil, ano IV, n. 4, 22 de setembro de 1980, e Balanço Anual da Gazeta Mercantil, ano IX, n. 9, 31 de julho de 1985. 
Tabela 1 - Posição ocupada pelos grupos têxteis de capital aberto do Vale do Itajaí no ranking dos 300 maiores grupos do país

\begin{tabular}{l|c|c}
\hline GRUPO & $1980^{\star}$ & 1985 \\
\hline Hering & $86 \mathrm{a}$ & $66 \mathrm{a}$ \\
\hline Artex & - & $103 \mathrm{a}$ \\
\hline Renaux & $168 \mathrm{a}$ & $214 \mathrm{a}$ \\
\hline Karsten & - & $215 \mathrm{a}$ \\
\hline Cremer & - & $196 \mathrm{a}$ \\
\hline
\end{tabular}

Fonte: elaboração própria a partir de Balanço Anual da Gazeta Mercantil, ano IV, n. 4, 22 de setembro de 1980; Balanço Anual da Gazeta Mercantil, ano IX, n. 9, 31 de julho de 1985.

* Algumas empresas como Artex, Karsten e Cremer ainda não constam nos anos 1980 dentre as 300 maiores, mas aparecem nos dados de 1985.

Em 1980, além da Hering, apenas uma outra empresa têxtil do Vale do Itajaí (SC) estava entre as maiores do país - a Renaux. Cinco anos depois, contudo, houve significativo avanço: Hering, Artex, Renaux, Karsten e Cremer - todas da mesma região - apareciam entre as 300 maiores empresas do país, sendo a Hering a com melhor posição dentre estas, constituindo-se na 66 maior empresa (de todos os ramos industriais) do Brasil em 1985.

O tamanho do grupo Hering no início da década de 1980 pode ser observado no Quadro 3, que mostra as empresas controladas. O grupo Cia. Hering, juntamente com suas empresas associadas, passou a ter a marca significativa de 31 empresas.

Quadro 3 - Empresas pertencentes à Cia. Hering e associadas

\begin{tabular}{|l|l|}
\hline Comercial Hering S/A e controladoras & \multicolumn{1}{c|}{ Ceval Agroindustrial S/A e Com. } \\
\hline Agropecuária Virapuru Ltda. & Ceval Óleos Vegetais S/A \\
\hline Ceval Agrícola S/A & Seara Brascarne Participações Ltda. \\
\hline Ceval Florestal S/A & Seara Brascarne S/A \\
\hline Ceval Export S/A & Seara Industrial S/A \\
\hline Ceval Internacional Ltda. & Seara Industrial Cotia S/A \\
\hline Soya Transportes Ltda. & Seara Avícola Xanxerê S/A \\
\hline
\end{tabular}

A publicação de 1980 faz um ranking das 250 maiores empresas privadas do país. A de 1985 refere-se as 300 maiores empresas privadas nacionais. 
Quadro 3 - Empresas pertencentes à Cia. Hering e associadas

\begin{tabular}{|l|l|}
\hline Comercial Hering S/A e controladoras & \multicolumn{1}{|c|}{ Ceval Agroindustrial S/A e Com. } \\
\hline Ceval Armazéns Gerais & Seara Paulista Comércio e Importações Ltda. \\
\hline Sagenética Reprodução Animal Ltda. & Seara Rio Comércio e Importações Ltda. \\
\hline Equipel S/A & Seara Brasília Comércio e Importações Ltda. \\
\hline Hering do Nordeste S/A - Malhas & Frigorífico Itapiranga S/A \\
\hline Hering S/A Confecções & Frigoaves Itapiranga \\
\hline Tecanor & Frigorífico Rio da Luz S/A \\
\hline Indústria Ouro Branco Ltda. & Matadouro Frigorífico Oeste Ltda. \\
\hline Brasblue Indústria e Comércio Ltda. & \\
\hline Comercial Joto S/A & \\
\hline Companhia Têxtil Santa Catarina & \\
\hline Garema S/A & \\
\hline $\begin{array}{l}\text { Fibranor Corretagens e Representações } \\
\text { Ltda. }\end{array}$ & \\
\hline
\end{tabular}

Fonte: elaboração própria a partir de Vieira Filho, apud Machado (2010, p. 60).

Dentre as empresas criadas, havia algumas exclusivamente voltadas à área frigorífica, principalmente no ramo de aves, conhecidas pela marca Seara. Além disso, ela passou a ter empresas no setor de óleo, além de genética, informática (Equipel) e corretagem (Fibranor), principalmente voltada à área de negociação de commodities. No têxtil, as subsidiárias envolviam tanto a parte industrial quanto a comercial.

Não só houve diversas divisões por setores, como também houve a criação de subsidiárias para atuação no Nordeste brasileiro e para exportações.

De acordo com Lago (apud Luclktenberg, 2004), o conglomerado Hering, em 1989, como um todo empregava diretamente 32,4 mil pessoas.

Até então, mesmo com tantas mudanças e um crescimento vertiginoso enquanto grupo, era a família Hering que detinha o controle acionário dos negócios ${ }^{29}$. Essa situação não permanecerá nos anos 2000 , como será discutido a seguir.

29 Ver Balanço Anual da Gazeta Mercantil, ano IV,n. 4,22 de setembro de 1980, e Balanço Anual da Gazeta Mercantil, ano IX, n. 9, 31 de julho de 1985. 


\section{Anos 1990 e 2000: a financeirização, os novos espaços de acumulação e os avanços da atuação comercial}

A abertura econômica brasileira, entre 1989 e o início dos anos 1990, permitiu a concorrência de produtos importados sem que o Estado tivesse um plano para preparar as empresas brasileiras a isso. Naquele momento, o próprio comércio exterior liberalizado era tido como política industrial, a fim de estimular as empresas nacionais a serem mais eficazes e competitivas, ao se depararem com o concorrente importado. Ou seja, esperava-se uma modernização à esteira da chegada da concorrência, o que não ocorreu. Como consequência, o país começaria a viver nesse período uma situação distinta: uma desindustrialização relativa (Cano, 2008, 2014).

A abertura resultou em uma das piores crises do setor têxtil nacional. A decisão do governo brasileiro de utilizar os importados para fazer frente à alta inflação interna veio acompanhada por um mercado nacional retraído, com altos juros e com uma moeda nacional sobrevalorizada. Como reflexo sobre o setor têxtil, houve uma entrada maciça de matérias-primas importadas e produtos acabados que começaram a concorrer tanto em malharia e tecelagem de algodão como nas fibras têxteis artificiais e sintéticas.

Nesse contexto, houve uma flexibilização produtiva, seguindo o movimento que já vinha sendo feito pelas grandes corporações dos países centrais no pós-1960. Tornou-se mais comum a subcontratação de facções, empresas muitas vezes de fundo de quintal tocadas por trabalhadores que antes pertenciam aos quadros das empresas maiores e agora se tornavam seus prestadores de serviços (Andrade, 2002). Além disso, houve uma revisão da diversificação excessiva que algumas empresas haviam feito, com venda de ativos, ocorreu fechamento de unidades têxteis em Blumenau e região, ampliação da automação em alguns casos e "relocalização" espacial, tendo esta efeitos intraurbanos, inter-regionais e interestaduais ${ }^{30}$.

Como exemplos concretos das mudanças desse período, houve redução dos empregos diretos na Hering, para cerca de 4 mil no fim dos

30 Ver Siebert (2006). 
anos 1990 (Siebert, 2006). Esse número se manteria no início dos anos 2000 (Luclktenberg, 2004).

A política macroeconômica brasileira do fim dos anos 1990 fazia parte dos determinantes mais relevantes da situação crítica do setor, principalmente no que diz respeito à política cambial e de juros altos. $\mathrm{O}$ crédito estava caro, havia maior concorrência de importados e parte das têxteis catarinenses estavam endividadas em dólar e se depararam com uma desvalorização brusca da moeda no início de 1999. Isso fez com que muitas não conseguissem honrar os compromissos com seus credores (Jurgenfeld, 2009).

Diante do quadro dos anos 1990, a Hering realizou ampla terceirização de produção e fechou unidades têxteis, como a produção na Argentina. Também revisou sua diversificação excessiva e vendeu a empresa Ceval e se desfez de outras atividades que não estavam relacionadas ao têxtil, como informática. Além disso, expandiu-se para o Centro-Oeste brasileiro por incentivos fiscais, custos mais baixos de mão de obra, além da possibilidade de contratação de serviços de empresas terceirizadas, especializadas em produção têxtil, que substituiriam parte da sua produção própria a custos mais baixos (Luclktenberg, 2004; Siebert, 2006).

\subsection{O capital financeiro como sócio maior}

Nesse movimento estratégico da empresa a partir dos anos 1990, é possível observar o avanço do capital financeiro. Em certa medida, não há como não elevar o grau de financeirização, dado que esse movimento aparece como um determinante global dos negócios, uma espécie de novo "formato" de atuação. Esse acréscimo de fatia do capital financeiro dentro dos negócios representará uma mudança de foco da empresa ao retorno dos acionistas. Isto é, as decisões serão tomadas a partir de então tendo em vista a perspectiva de aumento de dividendos a serem distribuídos entre seus acionistas, preocupados com o crescimento da sua rentabilidade.

Na década de 2000, a ampliação da financeirização levará a uma diluição da fatia que cabia aos antigos controladores - principalmente a família fundadora - em benefício do capital financeiro. Mesmo que diluído em vários acionistas do mercado financeiro, quando analisadas 
as fatias que deterá, o capital financeiro terá a maioria das ações, exercendo, quando em conjunto, o comando majoritário dos negócios.

Para se ter uma ideia mais precisa das mudanças, em 1998, a Cia. Hering, empresa que controlava os negócios da Hering e representava seus fundadores, detinha uma participação de $81,26 \%$ das ações ON.A Cia. Hering representava a união das ações da Inpasa, de Ivo Hering (membro da família fundadora) e da empresa IPE Investimentos e Participações. Anos depois, essas empresas foram desmembradas. Nos anos 2000 , nota-se que a fatia representativa do capital fundador-familiar caiu significativamente e passou a corresponder a 45,46\%, praticamente a metade do que havia no fim dos anos 1990, e para 16,2\% em 2010 (Tabela 2).

Tabela 2 - Distribuição das ações ordinárias da Hering (em \%)

\begin{tabular}{|c|c|c|c|c|c|}
\hline ACIONISTAS & 1998 & 2000 & 2005 & $2008^{\star}$ & $2010^{\star \star}$ \\
\hline \multicolumn{6}{|l|}{ Família Hering } \\
\hline Cia. Hering & 81,26 & - & - & - & - \\
\hline Inpasa & - & 22,76 & 22,76 & 9,08 & 9 \\
\hline Ivo Hering & - & 15,27 & 15,21 & 7,26 & 7,2 \\
\hline IPE Investimentos e Participações & - & 7,43 & 7,43 & - & - \\
\hline Total da família & 81,26 & 45,46 & 45,4 & 16,34 & 16,2 \\
\hline \multicolumn{6}{|l|}{ Demais acionistas } \\
\hline Caixa Previdência Func. Banco do Brasil & 16,72 & 5,75 & 5,75 & - & - \\
\hline Tarpon & - & - & - & 18,37 & 6 \\
\hline HSBC Global Investment Fund Ltd & - & - & - & 11,23 & 5,9 \\
\hline Federated Kaufmann Fund & - & - & - & 4,99 & 4,5 \\
\hline THE M T B O J T F H BR MOT FD & - & - & - & 6,59 & - \\
\hline Amundi Asset Management & - & - & - & - & 5 \\
\hline Target Investment Fund & - & - & - & - & 4,8 \\
\hline Outros $\star \star \star$ & 2,02 & 48,79 & 48,85 & 37,45 & 57,6 \\
\hline Total geral & 100 & 100 & 100 & 100 & 100 \\
\hline
\end{tabular}

Fonte: elaboração própria a partir de informações enviadas à BOVESPA.

Obs.: as participações das empresas que pertencem à família Hering estão destacadas.

^ Em 2007, a empresa entrou para o Novo Mercado, de modo que isso pode ter impactado na mudança significativa de participação da família observada nos dados de 2008.

$\star \star$ Para os dados de 2010, não se utiliza IAN, que deixou de ser publicado e foi substituído pelo ENET, formulário de referência, também enviado à BOVESPA.

$\star \star \star$ Por lei, as empresas não são obrigadas a informar quem são os acionistas que possuem menos de $5 \%$ de suas ações, reunindo-os na denominação "outros". 
Do mesmo modo que ocorreu a redução da fatia dos representantes da família fundadora no controle dos negócios, houve ampliação da fatia dos acionistas denominados "outros", que são os chamados acionistas minoritários. Estes, em 1998, detinham apenas 2,02\% do capital, passaram a representar 48,79\% em 2000 e chegaram a 57,6\% em 2010 (Tabela 2).

Em 2008, também há quatro novos acionistas com fatias significativas, todos representantes do mercado financeiro, na forma de fundos. Há a entrada do Tarpon, do HSBC Global Investment Fund, do Federated Kauffmann Fund e do fundo THE M T B O J T F H BR MOT FD. Somando as fatias desses fundos, eles possuíam, em 2008, 41,18\% do capital acionário total da Hering. Em 2010, reduziram sua participação para $26,2 \%$, mas ainda mantinham uma importante fatia.

O importante a notar é que, quando se adiciona a esses 41,8\% a participação de todos os minoritários, que detinham, em 2008, um total $37,45 \%$ das ações, nota-se que os fundadores não mais possuíam o controle do negócio, pois a fatia do capital financeiro como um todo ultrapassaria 70\%. Em 2010, somando a participação dos minoritários e dos demais fundos, o capital financeiro detém mais de 80\% do negócio.

\subsection{O Novo Mercado e os derivativos}

Há pelo menos dois outros indicativos relevantes que ajudam a mostrar o avanço da financeirização na Hering. O primeiro foi a entrada para o chamado Novo Mercado ${ }^{31}$ em 2007. O segundo foi o uso de instrumentos financeiros derivativos, um mecanismo de valorização do capital financeiro, observado após o estouro da crise mundial de 2007-2008.

31 O Novo Mercado, segundo explicação da própria BOVESPA, foi um segmento especial de listagem de ações, implantado em 2000, com o objetivo de proporcionar um "ambiente de maior interesse dos investidores" e uma "valorização das companhias". De acordo com a BOVESPA, no Novo Mercado, há maiores "compromissos de governança corporativa" pelas empresas, como prestação de informações que facilitam o acompanhamento e a fiscalização dos atos da administração e dos controladores da companhia e adoção de regras societárias que melhor equilibram os direitos de todos os acionistas, independentemente da sua condição de controlador ou investidor. Disponível em <http://www.bmfbovespa.com.br/pt_br/listagem/ acoes/segmentos-de-listagem/novo-mercado/>, acesso em 3 de agosto de 2017. 
A própria Hering definiu em seu relatório financeiro de 2007 que o significado prático de entrar para o Novo Mercado era participar mais ativamente no mercado de capitais. A justificativa da empresa era ter uma "estrutura de capital mais sólida", que, aliada ao fortalecimento da estrutura organizacional, permitiria a consolidação dos investimentos dos próximos anos: abertura de lojas próprias, tecnologia de informação e tecnologia industrial.

O Novo Mercado aumentou a participação de ações negociadas em bolsa (free-float) para aproximadamente 60\%. Com essa emissão de ações, a empresa atraiu investidores estrangeiros, que em 2008 já representavam $38,7 \%$ de seu capital social (Relatório financeiro da Hering, 2007).

Após adentrar o Novo Mercado, a Hering mostrava a necessidade de se fazer rentável de forma a preservar os seus novos sócios. Tanto que colocava como principal meta para 2008 o aumento na liquidez das ações, estreitando o relacionamento com o mercado de capitais. A Hering indicava, assim, atender os anseios dos acionistas (Relatório financeiro da Hering, 2007).

Dentre os resultados dessa ampla financeirização, a Hering passou a ter um valor de mercado bem maior do que as suas receitas operacionais líquidas. $\mathrm{O}$ valor de mercado representa a percepção que o mercado financeiro possui da empresa e mostra o descolamento entre aquilo que é resultado de operações de fato e o quanto a mais essa empresa valeria para uma venda, por exemplo. Em 31 de dezembro de 2009, as ações da Hering estavam cotadas a $\mathrm{R} \$ 29,35$, chegando, durante o último trimestre, a patamares inéditos (acima dos $\mathrm{R} \$ 34,00)$ na história da companhia. Seu valor de mercado chegou próximo a US\$ 1 bilhão $(O$ Estado de S. Paulo, 2012, s.p.).

Tabela 3 - Valor de mercado da Hering $\star$

\begin{tabular}{l|c|c|c|c|c|c}
\hline & 2001 & 2003 & 2005 & 2007 & 2009 & 2011 \\
\hline $\begin{array}{l}\text { Receita líquida } \\
\text { operacional }\end{array}$ & 145.753 & 103.047 & 136.837 & 208.459 & 414.052 & 721.416 \\
\hline $\begin{array}{l}\text { Lucro líquido/ } \\
\text { prejuízo líquido }\end{array}$ & -25.240 & 4.006 & 13.231 & 10.553 & 65.790 & 158.479 \\
\hline Valor de mercado & 46.199 & 44.216 & 38.958 & 319.671 & 910.723 & 2.828 .094 \\
\hline
\end{tabular}

Fonte: elaboração própria a partir de Economática.

*Valores em US\$ milhares. 
Nota-se, conforme Tabela 3, que o valor de mercado da Hering quase triplicou de 2007 - ocasião em que entrou para o Novo Mercado - para 2009 e mais que triplicou de 2009 para 2011. Outra novidade é que antes de 2007 o seu valor de mercado não era superior à sua receita líquida operacional. Em 2005, por exemplo, o valor de mercado perfazia US\$39 milhões, enquanto sua receita líquida operacional chegava a US\$136,8 milhões ${ }^{32}$.

De 2007 em diante, a situação é inversa. O valor de mercado da Hering se distanciou dos seus resultados de tal forma, que, no caso mais extremo, verificado em 2011, o lucro líquido da empresa era de US $\$ 158,5$ milhões e sua receita operacional líquida chegava a US\$ 721,4 milhões. Já o seu valor de mercado era quase quatro vezes superior à sua receita, chegando próximo a US\$ 3 bilhões (Tabela 3).

No Novo Mercado, a empresa estabelece uma relação mais estreita com os demais acionistas, inclusive, os minoritários, e um diálogo mais constante com fundos de pensão e de investimentos, também sócios do negócio. Isso ocorre porque no Novo Mercado as ações deixam de ser classificadas como preferenciais (sem direito a voto) ou ordinárias (com direito a voto). Todos acionistas têm direito a voto. Assim, ao mesmo tempo em que ampliava sua capitalização, a empresa no Novo Mercado se tornaria ainda mais dependente do "mercado".

Ainda que se justifique a entrada no Novo Mercado para captação de recursos para investimentos, a empresa - quanto mais líquida em bolsa - também passa a ter maiores possibilidades de uso de recursos financeiros para especulação e obter resultados no seu balanço proveniente de aplicações financeiras.

Essa perspectiva de ganhos financeiros se evidenciou, por exemplo, quando a Hering buscou as operações de derivativos, conhecidos como contratos futuros de venda de dólares, contratos futuros de compra de dólares, contratos de swap de dólar por CDI e contratos de swap de CDI por dólar.

$\mathrm{O}$ uso de Instrumentos Financeiros Derivativos (NDFs, da sigla em inglês) revelou-se no Brasil após a crise de 2007-2008, iniciada nos Es-

32 O desempenho da Hering a levou de volta ao ranking das maiores empresas do país depois de mais de uma década longe dele. Em 2011, entrou no ranking Valor 1000, do jornal Valor Econômico. VerValor 1000, Valor Econômico, ano 12, n. 12, ago. 2011. 
tados Unidos. A partir de então, como num efeito dominó, várias operações financeiras desse tipo começaram a aparecer nos relatórios financeiros das empresas brasileiras, que, até então, sequer informavam a seus acionistas a existência de tais operações.

Os derivativos foram ofertados no mercado por bancos no Brasil como forma de hedge cambial. Tratava-se de uma proteção cambial. Se a empresa está muito alavancada em dívidas em dólar, por exemplo, ela se "protegeria" com alguma operação financeira lastreada em dólar para fazer frente a essa dívida no futuro, para não depender unicamente do seu faturamento em reais, que pode ser arriscado por conta da oscilação da moeda no mercado de câmbio. A crise de 2007-2008, com forte impacto sobre os mercados financeiros, afetou essas operações, e, dependendo do tamanho dessas aplicações financeiras e da direção da "aposta" cambial da empresa, algumas tiveram expressivo prejuízo financeiro e tiveram que ser vendidas ${ }^{33}$.

A Hering justificou o uso de derivativos como forma de reduzir os riscos inerentes das suas operações. Ela realizou derivativos a partir de operações de swap e de contratos futuros de dólar. Eram usados como hedge dos seus fluxos de importações, exportações e pagamentos de empréstimos e financiamentos. O saldo em 31 de dezembro de 2007 de derivativos era de US $\$ 16$ milhões, com vencimento de janeiro de 2007 a agosto de 2008. Em 31 de dezembro de 2008, apresentou operações de compra futura de dólares em aberto, no valor de US $\$ 43,5$ milhões (Relatório financeiro da Hering, 2008).

O impacto dos derivativos no balanço financeiro de uma empresa pode ser positivo ou negativo. No caso da Hering, não houve impactos negativos. Em 2009, aliás, a Hering reportou que teve um resultado positivo de $\mathrm{R} \$ 24,8$ milhões referentes à reversão de parte do valor provisionado em 2008 sobre o valor dos Instrumentos Financeiros Derivativos. Ou seja, o encerramento de tais operações foi melhor do que o anteriormente esperado.

33 O caso Sadia é ilustrativo, pelo prejuízo de R\$2,5 bilhões em 2008. Após esse resultado, a empresa se fundiu com a empresa Perdigão. Disponível em <https:// economia.estadao.com.br/noticias/geral,derivativo-leva-sadia-a-prejuizo-de-r-2-5-bi,346128>, acesso em 30 de julho de 2018. 


\subsection{Novos espaços de acumulação: o "novo" Nordeste e o Centro-Oeste}

Nos anos 1990 e 2000, em meio ao processo de avanço da financeirização, e após as experiências iniciais dos anos 1970, houve um novo investimento da Hering no Nordeste. Esta estava baseada em uma nova fase de competição entre os estados para atração de investimentos, numa nova etapa da guerra fiscal. Os estados - para fazer frente à queda dos investimentos produtivos não só privados como estatais, dada a crise da década perdida dos anos 1980 - partiram para uma prática de concessão de subsídios ao capital privado, financiando uma parcela do imposto que deveria ser recolhido, amparados na maior autonomia que lhes era concedida pela Constituição de 1988 (Cardozo, 2010).

Nos anos 1990, houve a intensificação da disputa entre os estados com criação de fundos voltados ao financiamento de investimento fixo e ao capital de giro das empresas. Observa-se, portanto, que a guerra fiscal significaria um novo tipo de funding para as têxteis, pois com recursos públicos passariam a financiar suas novas operações. Cada estado passa a criar um ou mais programas de atração de empresas, com diversas reformulações ao longo do tempo, a fim de que sejam eleitos pelo capital produtivo, numa clara submissão das unidades federativas à lógica da acumulação de capital privado, com consequências perversas para as finanças públicas ${ }^{34}$.

Gorini e Siqueira (2002) ressaltam que no caso do Nordeste, além dos incentivos dados a projetos implantados na área sob a influência da SUDENE, o que significaria, por exemplo, a isenção do Imposto de Renda por dez anos, alguns estados também passaram a dar postergação do pagamento do Imposto sobre Circulação de Mercadorias e Serviços (ICMS). Aliados aos incentivos, ainda faziam parceria com as empresas para treinamento de mão de obra e criação de cooperativas de trabalhadores subcontratados na confecção, isentos de encargos sociais e remunerados de acordo com a sua produção.

A Hering se implantou novamente no Nordeste e incluiu o Centro-Oeste, ainda no fim dos anos 1990, como uma área nova a produzir da

\footnotetext{
34 Cardozo (2010) destaca que estado e município atraentes deixam de ganhar uma receita potencial e estado e município que antes abrigavam tais empresas perdem receita real.
} 
mesma forma que fazia em Santa Catarina: realizava uma parte da produção terceirizada e outra própria (que seria cada vez menor em magnitude do que a produção em terceiros). $\mathrm{Na}$ terceirizada, contratava oficinas de costura. Na produção própria, conseguia colocar mais turnos em suas unidades, pela maior oferta de mão de obra a custos mais baixos do que em Santa Catarina e pela baixa pressão sindical nessa região.

No Nordeste, dessa vez ela implantou uma fábrica no Rio Grande do Norte, em Parnamirim, no ano de 2000, e uma segunda unidade em 2009. A empresa passou a produzir tecido plano para calça e camisaria. No Centro-Oeste, onde se instalou inicialmente no fim dos anos 1990, passou a ter uma nova unidade em 2011, em Paraúna (GO) ${ }^{35}$, para talharia (cortes de tecidos), com investimentos de $\mathrm{R} \$ 5$ milhões. Essa unidade era abastecida também por uma rede de empresas terceirizadas que trabalhava para ela, totalizando quatro cidades - Anápolis, Goianésia, Santa Helena de Goiás e Paraúna. Assim, a expansão da empresa em Goiás envolveu municípios do interior do estado, com pouca atividade econômica, na maior parte dependentes de agricultura, e com população que não ultrapassava, àquela época, 50 mil pessoas (à exceção de Anápolis). Goiás se integraria ao seu modelo de negócios "híbrido", em que uma parte do produto era feita "em casa" e outra parte por terceiros.

De acordo com Siebert (2006), a ida da Hering para Anápolis resultou em fechamento de setores de costura das cidades de Blumenau (SC) e Indaial (SC). Essa mesma autora cita que em termos de custo de mão de obra, naquela época, uma costureira em Anápolis recebia um salário mais de três vezes inferior à média de Blumenau.

Desde os anos 1990, a empresa já vinha deixando claro que dava continuidade a um processo de desverticalização e ampliava o processo de terceirização. Em 1997, mais de 40\% das atividades de confecção já eram terceirizadas. Esse número cresceria gradativamente e em, 2008, a produção terceirizada, entre as diversas etapas de produção da companhia, respondia por aproximadamente 50\% (Relatório financeiro da Hering, 2009).

Em 2011, o presidente da empresa, Fabio Hering, afirmou que a produção total da empresa já estava dividida em 30\% em fábricas próprias,

35 Disponível em <http://www.jornalopcao.com.br/posts/ultimas-noticias/hering-tera-fabrica-em-parauna>, acesso em 3 de agosto de 2017. 
$45 \%$ terceirizados e $25 \%$ importados. Somando, portanto, importação e terceirização no país, 70\% dos produtos seriam em 2011 produzidos fora das instalações da Hering (O Estado de S. Paulo, 2012).

\subsection{O novo espaço "construído" na Ásia e o avanço da rede de lojas}

A produção da Hering em Santa Catarina, no Nordeste e no Centro-Oeste a partir dos anos 2000 ganharia o reforço de uma produção terceirizada pela empresa na Ásia. Em 2003, ela iniciou os estudos para realizar encomendas de produtos prontos na Ásia, o que se concretizou a partir de 2006. Desde o início, a busca se concentrou na produção de itens nos quais era necessária muita mão de obra na fabricação, comparativamente, como bermudas-cargo com oito bolsos (nesse caso, a mão de obra está concentrada na etapa da costura), e produtos feitos com fios sintéticos (especialidade dos asiáticos), como jaquetas de nylon para a coleção de inverno (Jurgenfeld, 2009, 2012).

A produção na Ásia ocorria cada vez de forma mais intensa porque o varejo de grandes redes, como C\&A, Renner, entre outros, já havia se antecipado com a compra de produção têxtil na Ásia. Se as empresas têxteis como a Hering não fizessem o mesmo, ficariam para trás na concorrência de preços com o varejo (Jurgenfeld, 2009, 2012).

A empresa contratava fornecedores principalmente na China, em Bangladesh e na Índia. Geralmente, a produção se dava em produto acabado: jaquetas, bermudas, calças, shorts de banho, suéteres, itens de tricô etc.

Em 2006, 3\% da produção total veio de fora do país. Em 2007, esse percentual cresceu para 5\% e, em 2008, para 12\%. Os itens fabricados na Ásia serviam tanto para vendas no mercado nacional quanto no exterior, mas a maioria se concentrava no mercado doméstico, um percentual que chegava a 95\%. Toda a produção asiática era feita com marca própria (Jurgenfeld, 2009, 2012).

Simultaneamente ao avanço da terceirização da produção, tornando-se uma compradora de produtos prontos, os anos 1990 e 2000 foram também representativos do aumento de importância da sua atuação comercial via redes de lojas próprias e franqueadas. Essa mudança é explicada pela empresa por conta da rentabilidade maior ao ir mais para 
frente na cadeia (varejo) do que para trás (produção de insumos). Em 1997, a Hering já colocava a ida ao varejo como prioritária e em 1998 dava mais informações do que isso significaria, ao informar que seu foco estava cada vez mais voltado às etapas mais rentáveis do processo de produção e distribuição (Relatório financeiro da Hering, 1997).

Em meio a esse processo, em 1998, não por acaso, a Hering criaria a rede de franquias de lojas Hering chamada Hering Store. Já em 1998, elas seriam 63 lojas. Nesse mesmo ano, abriria a primeira franquia de sua marca para crianças chamada PUC e 33 lojas da marca Dzarm, que foi adquirida em 1997.

Deve-se ressaltar que na operação de franquia a empresa comercializa sua marca para terceiros, que lhe pagam royalties, e lhe vende, em troca, serviços e mercadorias. O simples fato de ser proprietária de uma marca, portanto, nesse tipo de operação já lhe aufere ganhos.

Em 2002, a Hering decidia definitivamente pelo varejo, quando traçara um plano estratégico com foco em suas marcas-chave e em canais de distribuição mais rentáveis, o que representou a saída do grande varejo, como supermercados e grandes lojas de departamento (Relatório financeiro da Hering, 2006). No fim de 2006, já totalizava 190 lojas, sendo 151 lojas Hering Store e 39 da marca PUC, contava com 19 lojas franqueadas em países da América Latina e no Oriente Médio (Relatório financeiro da Hering, 2006).

\section{Considerações finais}

A análise histórica sobre as transformações do capital da empresa Hering representa um exemplo de como a grande corporação capitalista tenta se modificar, de forma a se adaptar às mudanças impostas pelas modificações do capitalismo mundial.

O estudo focado no pós-1960 permite perceber o seu movimento rumo à financeirização, que se inicia com a abertura de capital em bolsa de valores e se aprofunda, sobretudo, entre os anos 1990 e 2000, com o avanço do capital financeiro no seu capital social e também na sua própria atuação no mercado financeiro, com aplicações especulativas, como no uso de instrumentos financeiros derivativos, em busca de ganhos de curto prazo. 
Após a década de 1990, observou-se a maciça participação de acionistas do mercado financeiro, especialmente, os fundos de investimentos, inclusive muitos deles estrangeiros, como novos sócios do negócio Hering. Quando somadas as participações acionárias individuais desses acionistas, eles ultrapassaram a fatia detida pelos membros da família fundadora, detendo proporções elevadas do capital, superando $50 \%$. Ou seja, passam a deter o controle e, assim sendo, exercem influência sobre a gestão e estratégia dos negócios, de forma que a empresa passa a ter como objetivo maior valorizar a participação desses acionistas.

As modificações dadas pela financeirização também significaram mudanças espaciais. Entre os anos 1960 e 1980, houve novos espaços geográficos, como o Nordeste, e alguns municípios da própria região do Vale do Itajaí, no entorno da sua matriz, que foram incorporados ao movimento de centralização e concentração do capital e que ajudaram a conformar um dos maiores grupos empresariais do país na década de 1980, com outras vinculações setoriais. Entre os anos 1990 e 2000, uma nova espacialização ocorreu, com a incursão no Centro-Oeste, uma nova experiência no Nordeste e a incorporação da produção terceirizada na Ásia à sua dinâmica de acumulação.

Essas mudanças espaciais significaram redução dos seus vínculos com o seu espaço de origem, representado por Blumenau e pelo Vale do Itajaí (SC), e redução da sua atuação enquanto uma indústria produtora de artigos têxteis. Ao mesmo tempo que houve o avanço do capital financeiro, a empresa passou a focar cada vez mais seu negócio na área comercial: ampliou as operações de lojas, além de expandir a compra de produtos prontos fabricados por terceiros, reduzindo a importância da participação de sua produção fabril própria no total produzido e comercializado.

\section{Jornais e relatórios}

A ETIQUETA que tem nome de moda faz 50 anos. Folheto Institucional da Empresa

Mafisa, ano 50, s.d.

A FÓRMULA básica. O Estado de S. Paulo, 9 de abril de 2012, s.p.

BALANÇO Anual da Gazeta Mercantil, ano IV, n. 4, 22 de setembro de 1980.

BALANÇO Anual da Gazeta Mercantil, ano IX, n. 9, 31 de julho de 1985. 
ECONOMÁTICA.Valor de mercado da Hering. Sistema disponível somente por assinatura. Disponível em <www.economatica.com.br>. Acesso em 26 de agosto de 2012.

NASCE a Ceval. Folheto Institucional da Empresa Ceval, 2. ed. rev., jul. 1992.

O BANCO INCO e sua contribuição. O Vale do Itajaí: Lavoura, Indústria e Comércio, 1950, s.p.

RELATÓRIO financeiro da Hering, 1997, 2006, 2007, 2008, 2009. BOVESPA. Disponível em <http://www.b3.com.br/pt_br/produtos-e-servicos/negociacao/renda-variavel/empresas-listadas.htm>. Acesso em 10 de julho de 2017.

VALOR 1000, Valor Econômico, ano 12, n. 12, ago. 2011.

\section{Referências bibliográficas}

ANDRADE, G. Dinâmica competitiva das micro e pequenas empresas no cluster industrial têxtil-vestuário do Vale do Itajaí. Florianópolis: Centro Socioeconômico/Universidade Federal de Santa Catarina (UFSC), 2002 (Dissertação de Mestrado).

BELLUZZO, L. G. M. Prefácio. In: CHESNAIS, F. (org.). A finança mundializada: razões sociais e políticas, configuração, consequências. São Paulo: Boitempo, 2005.

BLOCK, F. Las orígenes del desorden económico internacional. México: Fondo de Cultura, 1980.

BOSSLE, O. História da industrialização catarinense: das origens à integração no desenvolvimento. Florianópolis: Edição Comemorativa da Confederação Nacional da Indústria (CNI) e Federação das Indústrias do Estado de Santa Catarina (FIESC), 1988.

BRAGA, J. C. S. Financeirização global: o padrão sistêmico de riqueza do capitalismo contemporâneo. In: FIORI, J. L.; TAVARES, M. C. (orgs.). Poder e dinheiro: uma economia política da globalização. Petrópolis:Vozes, 1997.

BRAGA, J. C. S. Temporalidade da riqueza: teoria da dinâmica e financeirização do capitalismo. Campinas: Instituto de Economia, UNICAMP, 2000 (Coleção Teses).

BRANDÃO, C. Território e desenvolvimento: as múltiplas escalas entre o local e o global. Campinas: Editora da UNICAMP, 2007.

BRANDÃO, C. Producción social del ambiente construido y sus escalas espaciales: notas para una teoría acerca de las acciones y decisiones de sujetos concretos. In: FERNANDEZ,V.R.;BRANDÃO, C. (orgs.). Escalas y politicas del desarrollo regional: desafios para América Latina. Santa Fe: Miño y Dávila, 2010.

BROOS, H.; SOCORRO, F. A Hering de Blumenau: um século (1880-1980). Blumenau: Edição Comemorativa do Centenário da Hering, 1980.

CAMPOS, R. Mudança e capacitação tecnológica em setores industriais selecionados de Santa Catarina: um estudo sobre as condições locais de aprendizagem e efeitos sobre a competitividade. Florianópolis: Centro Socioeconômico/Universidade Federal de Santa Catarina (UFSC), 2001 (Relatório de Pesquisa). 
CANO, W. Desconcentração produtiva regional do Brasil: 1970-2005. São Paulo: Editora UNESP, 2008.

CANO, W. Reflexões sobre o papel do capital mercantil na questão regional e urbana do Brasil. Texto para Discussão do IE-UNICAMP, n. 177, 2010.

CANO, W. (Des)industrialização e (sub)desenvolvimento. Cadernos do Desenvolvimento. Rio de Janeiro, v. 9, n. 15, jul.-dez. 2014.

CARDOZO, S.A. Guerra fiscal no Brasil e alterações das estruturas produtivas estaduais desde os anos 1990. Campinas: Instituto de Economia, Universidade Estadual de Campinas (UNICAMP), 2010 (Tese de Doutorado).

CHESNAIS, F. A globalização e o curso do capitalismo de fim de século. Economia e Sociedade. Campinas, v. 4, n. 2, dez. 1995.

CHESNAIS, F. A mundialização do capital. São Paulo: Xamã, 1996.

CORRÊA, R. L. Trajetórias geográficas. Rio de Janeiro: Bertrand Brasil, 2010.

DEAN, W. A industrialização de São Paulo. São Paulo: DIFEL, 1971.

DEEKE, J. O município de Blumenau e a história do seu desenvolvimento. Blumenau: Nova Letra, 1995.

EICHENGREEN, B. A globalização do capital: uma história do sistema monetário internacional. São Paulo: Editora 34, 2000.

GORINI, A. P. F.; SIQUEIRA, S. H. G. Complexo têxtil brasileiro. Rio de Janeiro: Edição do BNDES, 2002.

GOULARTI FILHO,A. Formação econômica de Santa Catarina. Florianópolis: Editora da UFSC, 2007.

HARVEY, D. A produção capitalista do espaço. São Paulo: Annablume, 2005.

HERING, I. Desenvolvimento da indústria blumenauense. Centenário de Blumenau (1850-1950). Blumenau: Edição da Comissão de Festejos, 1950.

HERING, M. L. R. Colonização e indústria no Vale do Itajaí: o modelo catarinense de desenvolvimento. Blumenau: Edição da Autora, 1987.

HILFERDING, R. O capital financeiro. São Paulo: Nova Cultural, 1985.

HOBSBAWM, E. Era dos extremos: o breve século XX, 1914-1991. São Paulo: Companhia das Letras, 2016.

HOBSON, J. A. A evolução do capitalismo moderno: um estudo da produção mecanizada. São Paulo: Abril, 1993.

JUR GENFELD,V. F. Transformando ameaça em vantagem: novos acenos da indústria têxtil-vestuarista do Vale do Itajaí com a Ásia. Florianópolis: Centro Socioeconômico/ Universidade Federal de Santa Catarina (UFSC), 2009 (TCC - Monografia).

JURGENFELD,V. F. Transformações dos grandes grupos têxteis de Blumenau e Brusque após 1970: a financeirização e os novos espaços de acumulação. Campinas: Instituto de Economia, Universidade Estadual de Campinas (UNICAMP), 2012 (Dissertação de Mestrado).

LINS, H. N. Reestruturação industrial em Santa Catarina: pequenas e médias empresas têxteis e vestuaristas catarinenses perante os desafios dos anos 90. Florianópolis: Editora da UFSC, 2000. 
LIVRO de ouro comemorativo do Centenário da Independência do Brasil e da exposição internacional do Rio de Janeiro, 7 de setembro de 1922 a 7 de setembro de 1923. Rio de Janeiro: Edição do Annuario do Brasil (Almanaque Laemmert), 1922. Disponível em <http:// docvirt.com/docreader.net $/$ DocReader.aspx?bib $=$ mhn\&pagfis $=26239>$. Acesso em 20 de julho de 2018.

LUCLKTENBERG, I. A. B. A indústria têxtil catarinense e o caso da Cia. Hering. Presidente Prudente: Geografia, Universidade Estadual Paulista (UNESP), 2004 (Dissertação de Mestrado).

MACHADO, L. M. Estratégias de crescimento no setor têxtil catarinense: o caso da Cia. Hering S.A. Florianópolis: Centro Socioeconômico/Universidade Federal de Santa Catarina (UFSC), 2010 (TCC - Monografia).

MAMIGONIAN, A. Estudo geográfico das indústrias de Blumenau. Revista Brasileira de Geografia, jul.-set. 1965.

SANTOS, M. Técnica, espaço, tempo: globalização e meio técnico-científico informacional (1994). São Paulo: HUCITEC, 1996.

SAUVIAT, C. Os fundos de pensão e os fundos mútuos: principais atores da finança mundializada e do novo poder acionário. In: CHESNAIS, F. (org.). A finança mundializada. São Paulo: Boitempo, 2005.

SEYFERTH, G. A colonização alemã no Vale do Itajaí-Mirim: um estudo de desenvolvimento econômico. Brusque: Movimento, 1974.

SIEBERT, C. Indústria e estado: a reestruturação produtiva e o reordenamento territorial do Médio Vale do Itajaí. Florianópolis: Geografia, Universidade Federal de Santa Catarina (UFSC), 2006 (Tese de Doutorado).

SILVA, S. Expansão cafeeira e origens da indústria no Brasil. São Paulo: Alfa-Omega, 1986.

SOJA, E. Geografias pós-modernas: a reafirmação do espaço na teoria social crítica. Rio de Janeiro: Jorge Zahar, 1993 (1989).

STEIN, S. Origens e evolução da indústria têxtil no Brasil - 1850-1950. Rio de Janeiro: Campus, 1979.

TAVARES, M. C. Da substituição de importações ao capitalismo financeiro: ensaios sobre economia brasileira. Rio de Janeiro: Zahar, 1975.

THEIS, I. O processo de acumulação em Blumenau. In:THEIS, I.; MATTEDI, M. A.; TOMIO, F. (orgs.). Nosso passado (in)comum. Blumenau: Editora da FURB, 2000.

THEIS, I.; BUTZKE, L. O paradoxo da geografia no capitalismo mundializado: revisitando a lei do desenvolvimento desigual e combinado. In: GALVÃO, A. et al. (orgs.). Capitalismo: crises e resistências. São Paulo: Outras Expressões, 2012.

TROTSKY, L. História da Revolução Russa.V. 1. Rio de Janeiro: Paz e Terra, 1978.

VIDOR, V. Indústria e urbanização no nordeste de Santa Catarina. Blumenau: Editora da FURB, 1995.

VIEIRA FILHO, A. As raízes da industrialização, grupos empresariais catarinenses: origem e evolução (1880-1985). Florianópolis: Edição do Autor, 1986.

WACHTEL, J. P. Os mandarins do dinheiro. São Paulo: Nova Fronteira, 1988. 